\title{
Language and Emotional Knowledge: A Case Study on Ability and Disability in Williams Syndrome
}

\author{
Christine A. James
}

Received: 21 November 2008 / Accepted: 19 January 2009 /

Published online: 11 February 2009

(C) Springer Science + Business Media B.V. 2009

\begin{abstract}
Williams Syndrome provides a striking test case for discourses on disability, because the characteristics associated with Williams Syndrome involve a combination of "abilities" and "disabilities". For example, Williams Syndrome is associated with disabilities in mathematics and spatial cognition. However, Williams Syndrome individuals also tend to "have a unique strength in their expressive language skills", and are socially outgoing and unselfconscious when meeting new people. Children with Williams are said to be "typically unafraid of strangers and show a greater interest in contact with adults than with their peers." This apparently keen social knowledge is a counterexample to the discussion of disability among academic philosophers, especially philosophers in the early modern period. Locke infamously used the example of disability to claim that Descartes' arguments in favor of innate ideas were incorrect. On the contrary, Williams Syndrome may stand as an example of innate social knowledge; something that could benefit current discourse in philosophy, disability theory, and medical ethics.
\end{abstract}

Keywords Self-reflexive attitudes · Williams Syndrome · Sociability · Hyperlexia $\cdot$ Amygdala $\cdot$ Planum temporale

\section{Introduction}

The field of biosemiotics is concerned with the intersection of philosophy, biology, linguistics, and communication. Persons with disabilities may have a variety of biological, linguistic and communicative differences that relate to semiotic issues. In the case of some disabilities, there may actually be a combination of heightened abilities as well. The unique social and linguistic capabilities of Williams Syndrome have been discussed in terms of quality of life analysis in medical ethics, but the role

\footnotetext{
C. A. James $(\square)$

Department of Philosophy, Valdosta State University, Valdosta, GA 31698-0050, USA

e-mail: chjames@valdosta.edu
} 
of semiotics in the quality of one's life deserves additional research attention. To that end, this paper will show how a philosophical understanding of Williams Syndrome's abilities and disabilities in perception, language, and sociability can enrich our understanding of biosemiotics generally as well as the current critique of normalcy in disability studies.

In 2005, a collection entitled Quality of Life and Human Difference was published as part of the series by Cambridge University Press on Philosophy and Public Policy. Edited by Wasserman, Bickenbach and Wachbroit, the text analyzes recent developments in the theory behind quality of life assessments, examining how the idea of "quality of life" can be understood for persons with disabilities. The common model since the 1970s is the Health Related Quality of Life model or HRQL. This method emphasizes data that supposedly reflect both subjective and objective indicators of quality of life.

One such subjective indicator is the concept of "satisfaction." Satisfaction can refer to a variety of activities carried out by an individual on a daily basis, from successful independent bathing, to successful social relationships. "The discussion of subjective quality of life has been confused by the failure to make two basic distinctions... the first is that between satisfaction as a mental state - a feeling, mood, or affect - and as a judgment or belief... of feeling satisfied, in the sense of feeling pleasure or euphoria. This is very different from believing one's needs, desires or preferences are being satisfied. The former is a psychological state, which can be inapt but not mistaken, while the latter is a judgment, which can be mistaken." In evaluating quality of life, one must consider the individual's ability to interact and function as a social being. More recent theories of disability address the explicit ways in which society undercuts the person with a disability as a social being. The Union of the Physically Impaired Against Segregation defined disability as "the loss or limitation of opportunities to take part in normal life of the community on an equal level with others due to physical and social barriers." This shift in the definition of disability, from physical conditions, to external social responses, provides us with a framework for understanding how disability is compounded in an ongoing process of stigmatization and exclusion. Barriers may be overt and physical, matters of access; they may be covert or hidden, in terms of social exclusion; they may be endemic, reflected in the way that medical policies are shaped. Our construction of disability, and refinement of quality of life assessment in public health, has been shaped by added acknowledgment of the social context of disability. One such case is Williams Syndrome.

Williams Syndrome challenges many of the assumptions we have about the roots of knowledge, and social knowledge and also forces us to reframe our notions of "normalcy" and normal personal interactions. In discussing how public health policies are informed by hidden values and assumptions, Robert Wachbroit acknowledges that we have a transparency problem: the values that inform health policy must be transparent, and must be able to engage in critical self-reflection. ${ }^{2}$ Shelley Tremain, in her 2005 collection Foucault and the Government of Disability,

\footnotetext{
${ }^{1}$ Wasserman et al. (2005, pp. 8)

${ }^{2}$ Wasserman et al. (2005, pp. 39).
} 
makes the point in terms of Foucault's analysis of power relationships within spheres of discourse - especially regarding discourse that classifies individuals: "Foucault argued that, in recent times, practices of division, classification, and ordering around a norm have become the primary means by which to individualize people, who come to understand themselves in this mode."3 The categories we use to describe each other take on an illusory objectivity, and become internalized and reified in the individual subject. Foucault's recommendation was to analyze power through a new kind of counter politics, a "strategic reversibility" - an overt reframing of the classifications imposed on individuals, turning the classification itself into a form of resistance. In a variety of ways, Williams Syndrome challenges the discursive and governmental acts that form and define contemporary subjects, by limiting their conduct. ${ }^{4}$ The notion of what behavior is socially "normal" is carefully inscribed and shaped, especially given the socio-political context in which fear and terrorism dominate the daily life and the mass media viewed by the individual citizen.

First, I will explain what Williams Syndrome is. Next, I will explain how specific characteristics of Williams Syndrome relate to the early modern period of Western Philosophy. Finally, I will address recent work in the theory of disability and medical ethics. I will show how the Williams Syndrome research on "social cognition" enriches current understanding of disability.

\section{What is Williams Syndrome?}

Williams Syndrome is a condition that results in a variety of abilities and disabilities. Williams is marked by a deletion of a small amount of genetic material on the 7 th chromosome, specifically a hemizygous deletion of about 20 genes. It was first identified in 1961, and is a relatively rare condition, affecting approximately one in every 50,000 births. The genetic material affected in Williams Syndrome is responsible for the production of elastin, which affects the physical appearance of the face, teeth, and causes an increased incidence of heart valve defects. People with Williams Syndrome tend to have certain disabilities, notably problems with mathematical and spatial reasoning; but they also have a set of exceptional abilities, including sensitive hearing, perfect pitch, heightened musical ability; excellent verbal and linguistic ability, reading skills, and vocabulary; poise and self-assurance in social situations, combined with a friendly and outgoing positive attitude. How does this microdeletion of genetic material create this striking combination of deficiency and talent?

Research dealing with this question has been underway for more than a decade, including work done by neurolinguist Ursula Bellugi at the Laboratory for Cognitive Science at the Salk Institute for Biological Studies in La Jolla, California. Bellugi has published articles in journals such as Cognitive Neuroscience, explaining how

\footnotetext{
${ }^{3}$ Tremain (2005, pp. 6).

${ }^{4}$ Tremain (2005, pp. 10).
} 
the "hypersociability" of Williams Syndrome may have a specific basis in the genetic, neurophysiological, and neuroanatomical profile of the disorder. ${ }^{5}$

Belugi is also one of the leaders in a collaborative project between the Salk Institute and the University of California at Davis' Center for Neuroscience, under the auspices of the James S. McDonnell Foundation, is continuing study of the disorder, with special attention to the way that it produces heightened social cognition. ${ }^{6}$

\section{The Forest and the Trees: Williams and Primary and Secondary Qualities}

One aspect of Williams Syndrome involves a difference in how sounds and physical objects are perceived. Many of us who do not have perfect pitch might hear a chord as one sound. Touch-tones that we hear when we dial a phone are actually a combination of more than one note, but it is reasonable that most of us would think of them as one tone. In the case of Williams Syndrome, there is a heightened awareness of the parts that make up the wholes.

Ursula Bellugi illustrates this with "a test in which she briefly shows a card with a large letter D made up of many small Ys and asks children to reproduce what they saw. "Normal" children reproduce the figure accurately. Children with Down syndrome generally draw a large D, ignoring the little Ys. Children with Williams syndrome, however, will draw a collection of Ys, but it won't be arranged in the shape of a D. One group seems to see just the forest, while the other sees only the trees."7 (Robert Finn, 1991)
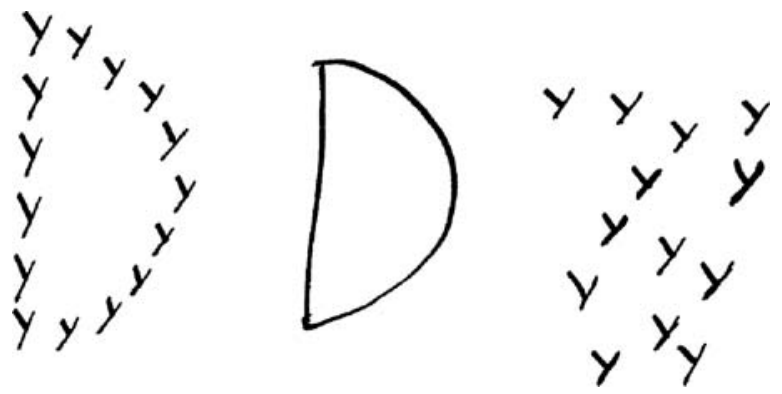

When asked to redraw a D made of Y's, children with Down Syndrome draw a D, children with Williams Syndrome will draw a collection of Y's.

A similar concentration on the pieces that make up the whole, or the trees that make up the forest, can be seen when Williams persons are asked to make a drawing. The drawings will have all parts of an object present, but the parts will not be

\footnotetext{
${ }^{5}$ Bellugi et al. (1999).

${ }^{6}$ Bellugi and Amarai 2002.

${ }^{7}$ Finn 1991, pp. 2
} 
connected in the right order. For example, a Williams drawing of a trombone will have all the valves and slides, the mouthpiece and the bell, but they will be disconnected or "exploded". 8

Elephant Drawing

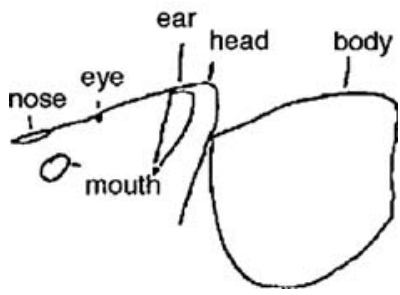

This drawing of an elephant by a child with Williams Syndrome shows a variety of the elephant's particular features, rearranged or "exploded" into a new order."

A philosophical understanding of the relationship between the features of an elephant, or the features of a human face portraying emotion, can help us to understand the differences in the daily experience of a person with Williams Syndrome. In later sections of this paper, these part-whole relationships will be related to the social ability of persons with Williams Syndrome. To an early modern philosopher, the specific attributes or pieces of an object would be described as a part of the manifold of experience. In the Monadology of 1714, Leibniz wrote of the manifold of human experience, and how each substance in the world must be made of parts that stand in a plurality of conditions and relations:

11. It follows from what has just been said, that the natural changes of the monad come from an internal principle, because an external cause can have no influence on its inner being.

12. Now besides this principle of change there must also be in the monad a variety (or manifoldness) which changes. This variety constitutes, so to speak, the specific nature and the variety of the simple substances.

13. This variety (manifold) must involve a multiplicity in the unity or in that which is simple. For since every natural change takes place by degrees, there must be something which changes and something which remains unchanged, and consequently there must be in the simple substance a plurality of conditions and relations, even though it has no parts.

14. The passing condition which involves and represents a multiplicity in the unity, or in the simple substance, is nothing else than what is called perception. This should be carefully distinguished from apperception or consciousness, as will appear in what follows. In this matter the Cartesians have fallen into a serious

\footnotetext{
${ }^{8}$ Finn 1991, pp. 2

${ }^{9}$ Thompson et al. 2005
} 
error, in that they deny the existence of those perceptions of which we are not conscious. It is this also which has led them to believe that spirits alone are monads and that there are no souls of animals or other entelechies, and it has led them to make the common confusion between a protracted period of unconsciousness and actual death. They have thus adopted the Scholastic error that souls can exist entirely separated from bodies, and have even confirmed ill-balanced minds in the belief that souls are mortal. ${ }^{10}$

Williams Syndrome also involves an emphasis on the parts that make up a whole, or "multiplicity in unity." Another example can be found in auditory perception of sounds, especially music and language. Silberman notes that, "many people with Williams also excel at picking out the notes in a chord. Some are so sensitive that they can identify the make and model of a car from the sound of its engine."11 At a music camp in Massachusetts, Williams and non-Williams children were given a clapping test. While the children in the non-Williams group would sometimes make a mistake and simply drop the beat, children with Williams would make mistakes that actually elaborated on the underlying rhythms - their mistakes were more like "jamming."12

Along with these heightened musical abilities, people with Williams Syndrome experience a sensitivity to sounds-low sounds or high pitched sounds can cause great pain to someone with the condition, while someone who does not have the syndrome might not even notice the sound at all. In the early modern period, philosophers described these differences in perception as secondary qualities that only exist in the mind of the perceiver. For example, Locke wrote:

Flame is denominated hot and light; snow, white and cold; and manna, white and sweet, from the ideas they produce in us. Which qualities are commonly thought to be the same in those bodies that those ideas are in us, the one the perfect resemblance of the other, as they are in a mirror, and it would by most men be judged very extravagant if one should say otherwise. And yet he that will consider that the same fire that, at one distance produces in us the sensation of warmth, does, at a nearer approach, produce in us the far different sensation of pain, ought to bethink himself what reason he has to say- that this idea of warmth, which was produced in him by the fire, is actually in the fire; and his idea of pain, which the same fire produced in him the same way, is not in the fire. Why are whiteness and coldness in snow, and pain not, when it produces the one and the other idea in us; and can do neither, but by the bulk, figure, number, and motion of its solid parts? ${ }^{13}$

\footnotetext{
${ }^{10}$ Leibniz (1714, pp. 456-7).

${ }^{11}$ Silberman (2003, pp. 1).

12 Silberman (2003, pp. 1).

${ }^{13}$ Locke (1690), book II, chapter 8, section 16, pp. 27.
} 
Berkeley (1713) responded to Locke by collapsing the difference between primary and secondary qualities in the Three Dialogues Between Hylas and Philonous:

$<$ Phil $>$. Is it therefore certain, that there is no body in nature really hot?

$<\mathrm{Hyl}>$. I have not denied there is any real heat in bodies. I only say, there is no such thing as an intense real heat.

$<$ Phil $>$. But, did you not say before that all degrees of heat were equally real; or, if there was any difference, that the greater were more undoubtedly real than the lesser?

$<$ Hyl $>$. True: but it was because I did not then consider the ground there is for distinguishing between them, which I now plainly see. And it is this: because intense heat is nothing else but a particular kind of painful sensation; and pain cannot exist but in a perceiving being; it follows that no intense heat can really exist in an unperceiving corporeal substance. But this is no reason wh' we should deny heat in an inferior degree to exist in such a substance.

$<$ Phil $>$. But how shall we be able to discern those degrees of heat which exist only in the mind from those which exist without it? ${ }^{14}$

We can draw an analogy between the sensitivity to sounds in Williams Syndrome and the sensitivity to heat described in the Locke/Berkeley debate. Williams Syndrome individuals clearly experience these secondary or in-the-perceiver qualities differently. Given that this is the case, is there a physical basis for this difference (perhaps a biological or chemical aspect of the brain that accounts for it), and does this same difference in the brain relate to Williams Syndrome's heightened social ability? There is a potential physical explanation for the auditory awareness. In both Williams individuals and in professional musicians with perfect pitch, the physical structures of the brain share specific similarities: "When most people listen to a piece of music, they track melody with the right hemisphere and rhythm with the left. But among professional musicians, both are tracked with the left, which handles behaviors that have become routine. MRI scans show that skilled violinists have enlarged areas of tissue in the left planum temporale, an auditory crossroads that serves both music and language." ${ }^{15}$ Williams Syndrome physiology usually involves an enlarged planum temporale as well.

We can also draw a connection between musical ability and language. Williams Syndrome is associated with a broad vocabulary that develops from a very young agewords will be used in the right place in a sentence, with slightly varied meanings, invoking a playful and poetic manipulation of language. In one instance, a researcher was given a drawing that a Williams child had made of her. As the child handed the drawing to her, instead of saying "this is a drawing of you", the child said "this is in remembrance of you." After receiving positive results on an intelligence test, a Williams Syndrome child remarked, "They said I have the genius of a regular student." The rich

\footnotetext{
${ }^{14}$ Berkeley (1713, pp. 223).

${ }^{15}$ Silberman (2003, pp. 2).
} 
vocabulary of Williams Syndrome children was also documented in comparison to Downs Syndrome children: "When Ursula Bellugi asked a child with Down Syndrome to name all the animals he could think of, the reply was "Dogs, cats, fish, bird, fish," A Williams Syndrome child of the same age and IQ answered "Brontosaurus, tyranadon, tyrannosaurus rex, dinosaurs, elephant, dog, cat, lion, baby hippopotamus, ibex, whale, bull, yak, zebra, puppy, kitten, tiger, koala, dragon." 16

The Williams Syndrome gift for language is also displayed in the tendency to create vivid, fantastic stories, detailed narratives involving myth, exaggeration, and dramatic storytelling. The "hyperlexia" associated with Williams has been well documented, including the case of a boy named Matt who insists that numbers are "friendly" and "amicable," and that the number 47 must be "lonely" because whenever people are asked to pick a random number, they tend not to pick the number $47 .{ }^{17}$

This gift for exaggeration, and looking at events from multiple points of view, reminds me of Berkeley's discussion of perception from the point of view of animals smaller and larger than humans, like the famous mite's foot example. In the Three Dialogues, Berkeley argued that:

$<$ Phil $>$. Besides, it is not only possible but manifest, that there actually are animals whose eyes are by nature framed to perceive those things which by reason of their minuteness escape our sight. What think you of those inconceivably small animals perceived by glasses? must we suppose they are all stark blind? Or, in case they see, can it be imagined their sight hath not the same use in preserving their bodies from injuries, which appears in that of all other animals? And if it hath, is it not evident they must see particles less than their own bodies; which will present them with a far different view in each object from that which strikes our senses? Even our own eyes do not always represent objects to us after the same manner. In the jaundice every one knows that all things seem yellow. Is it not therefore highly probable those animals in whose eyes we discern a very different texture from that of ours, and whose bodies abound with different humours, do not see the same colours in every object that we do? From all which, should it not seem to follow that all colours are equally apparent, and that none of those which we perceive are really inherent in any outward object? ${ }^{18}$

Perceptions that vary from one perceiver to another can also affect relative judgments of size, loudness, or discomfort. Later in the Dialogues Berkeley writes:

$<$ Phil $>$. Answer me, Hylas. Think you the senses were bestowed upon all animals for their preservation and well-being in life? or were they given to men alone for this end?

$<\mathrm{Hyl}>$. I make no question but they have the same use in all other animals.

\footnotetext{
${ }^{16}$ Finn 1991, pp. 2.

${ }^{17}$ Silberman (2003, pp. 1).

${ }^{18}$ Berkeley (1713, pp. 231).
} 
$<$ Phil $>$. If so, is it not necessary they should be enabled by them to perceive their own limbs, and those bodies which are capable of harming them?

$<$ Hyl $>$. Certainly.

$<$ Phil $>$. A mite therefore must be supposed to see his own foot, and things equal or even less than it, as bodies of some considerable dimension; though at the same time they appear to you scarce discernible, or at best as so many visible points?

$<$ Hyl $>$. I cannot deny it.

$<$ Phil $>$. And to creatures less than the mite they will seem yet larger?

$<$ Hyl $>$. They will.

$<$ Phil $>$. Insomuch that what you can hardly discern will to another extremely minute animal appear as some huge mountain?

$<$ Hyl $>$. All this I grant.

$<$ Phil $>$. Can one and the same thing be at the same time in itself of different dimensions?

$<$ Hyl $>$. That were absurd to imagine.

$<$ Phil $>$. But, from what you have laid down it follows that both the extension by you perceived, and that perceived by the mite itself, as likewise all those perceived by lesser animals, are each of them the true extension of the mite's foot; that is to say, by your own principles you are led into an absurdity. ${ }^{19}$

While Locke and Berkeley established the importance of perception and the qualities that reside in us as perceiving beings, we can still learn from them, especially regarding what we perceive as "normal" and what we perceive as "disabled". Individuals with Williams Syndrome have perceptual abilities that give them a deep focus on specific details of experience, whether physical features of objects like elephants, or sounds like musical notes that make up chords, or specific words. This ability to focus, when used in situations involving social interactions and emotional cues from other people's voices and faces, may be related to the apparent sociability of individuals with Williams Syndrome. Perhaps we can learn from this and use it in the context of a critique of "normalcy".

\section{Current Medical Ethics Literature: Who Is Really "Normal"?}

The current medical ethics literature represents a range of views on whether or not genetic research should strive to correct genetic abnormalities like Williams Syndrome. In their article titled, "Essentially Empirical: The Roles of Biological

${ }^{19}$ Berkeley (1713, pp. 234). 
and Legal Classification in Effectively Prohibiting Genetic Discrimination", Anita Silvers and Michael Ashley Stein note that

Science promises enormous public benefit, but simultaneously threatens significant social harm... Genomics, the study and application of genetic information, can identify asymptomatic individuals who are at risk of becoming ill or of transmitting inheritable illnesses to their children. In principle, people who test positively for potentially disabling genes could take various kinds of prophylactic measures to slow or stop manifestations of disease. ${ }^{20}$

The question remains: do we lose a significant part of our "humanity" as we strive to become "normal." Francis Collins, Direction of the U. S. National Human Genome Research Institute, estimates that all of us carry dozens of glitches in our DNA. ${ }^{21}$ This means that any claims to "normalcy" based on genomics will be inherently inaccurate and limited - what we assume to be normal reflects far-ranging variations at the level of genes themselves. The likelihood of discrimination against persons designated as genetically "defective" has been well documented. For example, in Mitchell and Snyder (2003) article, "The Eugenic Atlantic: race, disability, and the making of an international Eugenic Science, 1800-1945", it is noted that eugenics involves an unprecedented level of multi-national, scientific and governmental exchange over what to do with those designated as physically and cognitively "Other." They note that scholars have critiqued the Nazi eugenics programs in regard to racial categories, and that disability also came to be construed as a socially dehumanizing construct in tandem with theories of racial degeneracy. ${ }^{22}$

Current scholarship attempts to respond to, and dismantle, these dehumanizing assumptions in various ways. Silvers and Stein have argued for creating genetic discrimination protection "on the basis of genetic identity" for everyone, rather than just for "qualified individuals" who are symptomatic, or else who have positive results of predictive genetic testing but are not symptomatic. Everyone has a racial and a sexual identity, and a genetic identity as well. Further, everyone is genetically anomalous in some way. Everyone exhibits some difference from what we call "typical" or "normal", because the idea of "typical" or "normal" is as much an idealized construction as the idea of the "average man." 23

Could at least some of the characteristics of Williams Syndrome actually be used to broaden and enrich how we think of the "typical", "normal", "average man"? Licia Carlson engages in a related critique of normalcy in her 2003 article "Rethinking Normalcy, Normalization, and Cognitive Disability."

According to the traditional medical model of disability, disability is understood as the presence of certain physical or cognitive impairments, located in the individual, that are considered objectively "abnormal" and "undesireable." The emergence of disability studies and disability theory challenges us to address the

\footnotetext{
${ }^{20}$ Silvers and Stein (2003, pp. 129).

${ }^{21}$ Silvers and Stein (2003, pp. 130), also citing "Lawmakers Renew Push for Gene Discrimination Bill", Reuters Health, June 7, 2001, http://www.reutershealth.com/archive/2001/06/07/elione/links/ 20010607elin037.html

${ }^{22}$ Mitchell and Snyder (2003, pp. 851).

23 Silvers and Stein (2003, pp. 150).
} 
socially and historically determined nature of both the definitions and experiences of disability, and the concept of "normalcy" itself. There are numerous ways in which the very concept of the normal can be critiqued: the ontological status of the categories "normal" and "abnormal" can be questioned; the binary nature of this concept can be challenged; and the practices associated with the "normalization" of both disabled individuals and their environments have been called into question. ${ }^{24}$

The prospect of "normalizing" someone with Williams Syndrome is frought with assumptions, assumptions that will leave us devaluing the exceptional musical, linguistic and social ability associated with Williams. Carlson recommends a different approach, inspired by Georges Canguilhem's book The Normal and the Pathological (1991), where Canguilhem challenged the claim that normal and pathological states can be "objective", and by Alasdair MacIntyre's Dependent Rational Animals (1999) and its concept of "flourishing" in society.

Canguilhem argued that the concept of the normal is defined in part by virtue of the individual's relationship to the environment, and through a dynamic process. "The normal is not a static or peaceful, but a dynamic and polemical concept...to set a norm, to normalize, is to impose a requirement on existence. $^{25}$

Instead, we could argue that the enriched social knowledge of Williams Syndrome actually is a norm that we should strive for-perhaps the dynamic social process of Williams is itself a virtuous behavior, and we should see individuals with Williams as the exemplars, sources of moral education. The key here is to note that the relationship of individuals to the environment is different for individuals with Williams Syndrome, and that those differences may actually indicate a set of abilities that are to be valued. The ability to focus on specific details and rearrange them in new ways, and focus on emotionally informative parts of a situation, challenges the binary of normal/abnormal:

Canguilhem's work has profound implications for the medical model of disability. By dislodging the notion that the abnormal/normal binary exists objectively in nature, and by unmasking the process by which science covers its normative tracks, his work lends credence to the critique of the medical model of disability as "objectively abnormal." Moreover, insofar as the normal is a dynamic concept, Canguilhem suggests that it is in fact contingent and mutable, a fact evidenced in the complex history of changing definitions of "disability." 26

Carlson argues that it is important to go beyond an examination of the ways that the medical model of disability reifies the categories of normal/abnormal and recognize that the force of this binary may persist in spite of such science, not simply

\footnotetext{
${ }^{24}$ Carlson (2003, pp. 154).

${ }^{25}$ Carlson (2003, pp. 155).

${ }^{26}$ Carlson (2003, pp. 156).
} 
because of it. The importance of extending critiques of normalcy beyond the medical model becomes particularly evident when one considers cognitive disabilities. ${ }^{27}$

\section{Williams Syndrome and Social Knowledge: Who Is Really Disabled?}

So how does Williams Syndrome challenge our usual understanding of intelligence and disability? We tend to think of intelligence in terms of quantities, scores, or IQ tests. But people with Williams syndrome can show lots of intelligence in certain areas - language, music, and interpersonal relations, for example - and yet their IQ is typically between 50 and 70 , low enough to qualify them as moderately to mildly retarded... ${ }^{28}$

Although the apparent mental retardation of Williams Syndrome is documented, there is also abundant evidence of Williams Syndrome children's social gifts. A report from a team at the University of Delaware, led by Seth Stocking, notes that "They have serious deficits dealing with numbers, spatial cognition, and problem solving yet they preserve a "theory of mind" and have the ability to talk about others' beliefs." 29

A parent of a Williams Syndrome child soon finds that Williams Syndrome children seem to have a special or innate kind of social knowledge: "I learned a lot from Katey," she says of her now adult daughter. "When Katey was a little girl I was 23 and self-conscious. And here I had this little girl with all these problems, and she'd walk into a room with a group of people, never shy, never self-conscious, and say, 'Hi, my name's Katey. What's your name?' I would think, how did she do that? She makes it look so easy. She taught me how to forget about myself and just meet people." ${ }^{30}$

Can we describe this as an innate social knowledge? Descartes famously described the innate idea of God, but Locke sharply disagreed:

Every man being conscious to himself that he thinks; and that which his mind is applied about whilst thinking being the ideas that are there, it is past doubt that men have in their minds several ideas,- such as are those expressed by the words whiteness, hardness, sweetness, thinking, motion, man, elephant, army, drunkenness, and others: it is in the first place then to be inquired, How he comes by them? I know it is a received doctrine, that men have native ideas, and original characters, stamped upon their minds in their very first being. ${ }^{31}$

Could social knowledge be "stamped on our minds", or is social knowledge actually a matter of controlling our self-consciousness, our social fears? The mother of the Williams child applauded her child's lack of self-consciousness, and noted how it opened social doors for both her and her daughter.

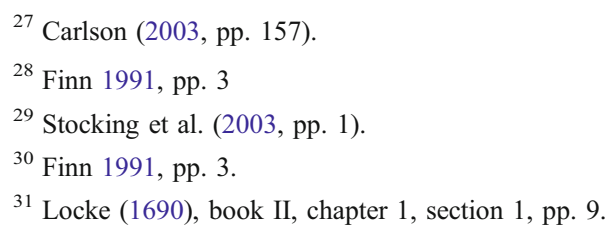


Philosophers describe this as avoiding the reflective act of self-awareness and self-criticism. Leibniz explained the ongoing process of reflective thinking in the Monadology:

30. It is also through the knowledge of necessary truths and through abstractions from them that we come to perform Reflective Acts, which cause us to think of what is called the I, and to decide that this or that is within us. It is thus, that in thinking upon ourselves we think of being, of substance, of the simple and composite, of a material thing and of God himself, conceiving that what is limited in us is in him without limits. These reflective acts furnish the principal objects of our reasonings. ${ }^{32}$

Leibniz's theory of perception, and the reflective acts which cause us to think of the "I", are undoubtedly important. But the Williams Syndrome ability to focus on other aspects of social interactions (other people's feelings, other people's faces, body language, non-verbal cues) actually are a way out of selfreflexive attitudes. Consider the work on self-reflexive attitudes by recent Philosophers of Mind, like Peter Strawson ${ }^{33}$ or Alfred Mele. ${ }^{34}$ They would find a great deal to say about the mother's reference to "forgetting about myself and just meeting people." When the quote unquote "normal" person struggles to forget themself in a social situation, philosophers of mind call this a "self-reactive attitude" or "being caught in a self-reflexive loop." Strawson outlines two types of reactive attitudes, which are 1) parts of a continuum of attitudes and intentions which others may hold towards us; and 2) the kinds of attitudes and feelings to which we ourselves are prone (Strawson 1963, 49-50). One major type of these reactive attitudes are those which are held by offended parties (parties who feel that they have been morally wronged by someone) or those of beneficiaries of good will (Strawson 1963, 56).

As Strawson describes them, self-reactive attitudes "look inward": they are attitudes which are associated with demands on oneself for others. In a self-reactive attitude, we place excessive demands upon ourselves, disabling our ability to interact socially and understand other people's feelings. It is a significant trait of Williams Syndrome that children and adults with Williams Syndrome are not hampered by self-consciousness or self-reflexive loops in this way. The fact that they do not suffer from the socially debilitating events that many of the rest of us do, shows that the standard model of ability and disability does not apply to their situation. The characteristic outward-looking, non-self-conscious attitude of those with Williams Syndrome is also apparent in facial recognition testing. When confronted with faces depicting emotions, and requested to name the emotion reflected on the face, Williams individuals regularly test better than people with "normal" intelligence. This research parallels work by Juan Jose Acero, whose

\footnotetext{
${ }^{32}$ Leibniz (1714, pp. 460).

33 See Strawson's Freedom and Resentment, 1963

34 See Mele's Motivation and Agency, 2003; Self-Deception Unmasked, 2001; Autonomous Agents: From Self-Control to Autonomy, 1995; Springs of Action: Understanding Intentional Behavior, 1992.
} 
"Emotion as Exploration" (2008) describes cultural differences between Japanese, American and European viewers of films - according to his findings, Japanese viewers often rely on context to interpret a scene in a film (based on their eye movement throughout a screening), while American viewers tend to concentrate on actor's faces and rely more on specific facial characteristics to interpret a scene.

a. Cartoon Faces (Experiment 1)

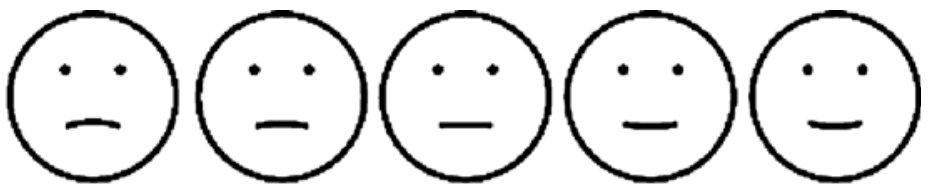

b. Ekman Face Set (Experiment 2)
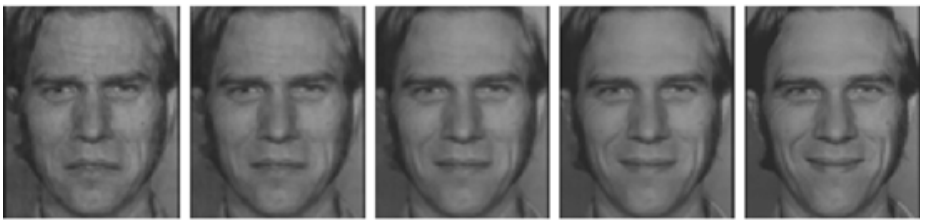

\section{c. MMI Face Set (Experiment 3 and 4)}
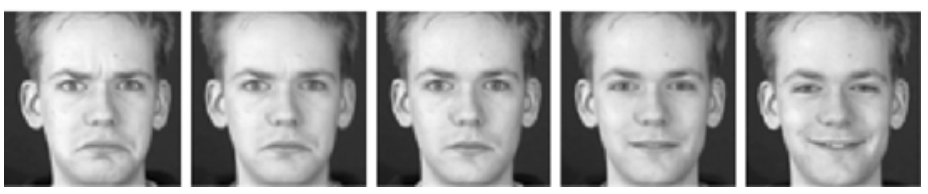

Children and adults with Williams Syndrome often score better than "normal" individuals when asked to identify emotions as portrayed in photographs and drawings of faces. $^{35}$

In point of fact, one can see Williams Syndrome in light of a Foucauldian "implantation of impairment" thesis - following the work of Barry Allen (2005), our added understanding of Williams Syndrome from the last 40 years is an example of added disciplinary knowledge and power that shows a range of individuals in the population we routinely classify as "normal" are actually socially impaired. ${ }^{36}$ Clearly the "knowledge" of individuals with Williams Syndrome is not a "subjugated" knowledge, it is a valuable capability that adds to quality of life. In parallel with Licia Carlson's work on mental retardation, I argue that the current historical context and renewed focus on social knowledge and social ability provides groundwork for persons with Williams to be seen as a new "kind" of person ${ }^{37}$ with heightened linguistic and social capabilities.

\footnotetext{
${ }^{35}$ Image reproduced in Deric Brown's mindblog: http://mindblog.dericbownds.net/2008_04_01_archive.html

${ }^{36}$ Tremain (2005, pp. 15).

${ }^{37}$ Tremain (2005, pp.17).
} 
The studies of cognitive activity in Williams individuals compare with neural images of persons engaged in activities that tend to reduce their self-reflexive attitudes (the classic examples being prayer, meditation, and volunteer work.). Scans of frontal lobe activity, as well as amygdala activity, show a heightened social awareness and concern for other's feelings.
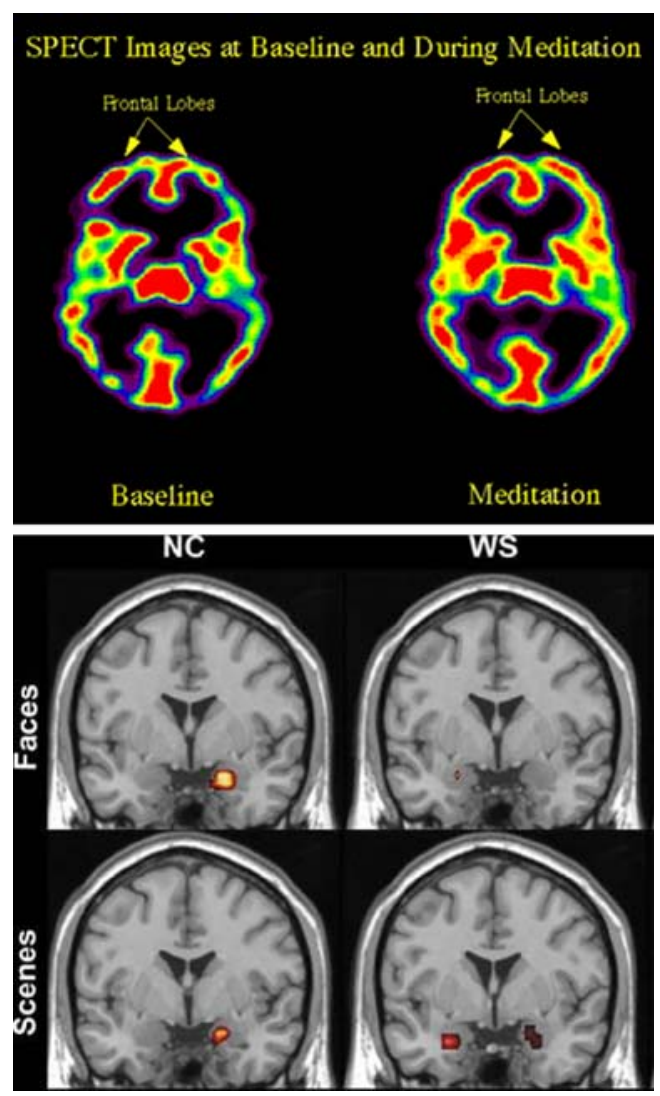

At the top, a comparison of brain activity at baseline ( $L$ ) and during meditation ( $R$ ). At the bottom, a comparison of brain activity in control groups (L) and in Williams Syndrome individuals $(R)$ when confronted with threatening faces and threatening scenes. ${ }^{38}$

\footnotetext{
38 "Scientists Uncover New Clues About Brain Function in Human Behavior" National Institute of Mental Health (NIMH), part of the National Institutes of Health, have discovered a genetically controlled brain mechanism responsible for social behavior in humans, one of the most important but least understood aspects of human nature. The findings were reported in Nature Neuroscience, July 10, 2005. http://www. nih.gov/news/pr/jul2005/nimh-10.htm Abnormal regulation of the amygdala in participants with Williams Syndrome (right) compared to controls (left). The amygdala activates more for threatening scenes (bottom), but less for threatening faces (top).
} 
The reframing of self-consciousness in social situations is borne out by the work of Allan Snyder. A researcher in Australia, Snyder hopes to give people therapeutic access to the raw data of their mind, (without the clouding effects of self-reflexive loops), by artificially stimulating the left temporal lobe. Snyder believes that the increased activity of the left temporal lobe will free the rest of the mind from distraction, especially social anxieties. The results of Snyder's work so far have been mixed. Researchers at Flinders University in Adelaide, Australia, couldn't replicate the results of Snyder's experiments. Volunteers who received temporal stimulation (TMS) showed no statistically significant improvement on tasks at which savants typically excel, except for a small increase in a test related to long-term memory. Some skills actually declined slightly. ${ }^{39}$

Williams Syndrome shows that what we consider "normal" may actually be deficient, especially in areas of social flourishing. What is it to be a normal, healthy, flourishing social being? Alisdair MacIntyre (1999) explains that the concept of flourishing is one and the same for all species: "Those who benefit from communal flourishing will include those least capable of practical reasoning... and their individual flourishing will be an important index of the whole community. For it is insofar as it is need that provides reason for action for the members of some particular community that that community flourishes." 40

Terms like "cognitive disability" and "mental retardation", are heterogeneous classifications. Historically, normalization has been a strategy explicitly tied to persons with cognitive disabilities. The program to integrate persons into the community and to teach them "normal" life skills and modes of being can be traced throughout the second half of the twentieth century. Wolf Wolfensberger, one of the central figures in the normalization movement, described it as follows: "The most explicit and highest goal of normalization must be the creation, support, and defense of valued social roles for people who are at risk of social devaluation." ${ }^{41}$ Because of a heightened ability to focus on parts of objects and parts of social interactions, some individuals such as those with Williams Syndrome, have better social capability and less limitation by self-reflexive attitudes. This is an admirable ability to understand

\footnotetext{
39 "Our knowledge and expertise blind us," Snyder says. "If we could switch off our conceptual mind, we could have a momentary literal viewing of the world." Where Snyder and his mentors part ways is on how to go about switching off the conceptual mind. His method is to create a "virtual lesion" in the left temporal lobes by bombarding them with magnetic pulses, using transcranial magnetic stimulation. Volunteers given TMS, Snyder says, draw more naturalistically, and their proofreading skills also improve, because they see what's in front of their eyes, rather than what their conceptual minds think they're seeing. Profiled in The New York Times Magazine last summer in an article called "Savant For a Day," Snyder has captured the imagination of the press by predicting that someday, anyone will be able to don a TMS "thinking cap" and boost their creativity with a dose of savant-style cognition. There's only one problem. Researchers at Flinders University in Adelaide, Australia, couldn't replicate the results of Snyder's experiments. Volunteers who received TMS showed no statistically significant improvement on tasks at which savants typically excel, except for a small increase in a test related to long-term memory. Some skills actually declined slightly." Silberman (2003, pp. 4).

${ }^{40}$ Carlson (2003, pp. 166-167).

${ }^{41}$ Carlson (2003, pp. 160); citing Wolf Wolfensberger, "Social Role Valorization: A Proposed New Term for the Principle of Normalization," Mental Retardation, 21:234-9.
} 
and focus on others' feelings. Williams Syndrome stands as an example of exactly those abilities, and disabilities, that we must not devalue.

Acknowledgements The author wishes to thank the organizers and participants in the Granada Workshop on Language and Emotion, which took place at the University of Granada in Granada, Spain in September 2008. An earlier version of this paper was presented at that conference.

\section{References}

Acero, J. J. (2008). Whose "Emotion as Exploration", was presented at the Granada Workshop on Language and Emotion, September 2008.

Allen, B. (2005). Foucault's Nominalism. In S. Tremain (Ed.), Foucault and the Government of Disability (pp. 93-107). Ann Arbor: University of Michigan Press 2005.

Bellugi, U., \& Amarai, D. G. (2002). "Williams and Social Cognition: The Impact of Williams Syndrome Mutations on Neural Organization and Brain Function: A Window into Social Cognition", James S. McDonnell Foundation, Collaborative Activity Award, Program Overview, http://mcdonnell.salk.edu/ md pro1.htm

Bellugi, U., et al. (1999). Towards the neural basis for hypersociability in a genetic syndrome, cognitive neuroscience. Neuro Report 10, 10(8), 1653-1657, 3, June 1999.

Berkeley, B. G. (1713). Three Dialogues Between Hylas and Philonous, In Opposition to Sceptics and Atheists, in The Empiricists. New York: Doubleday: 1961, 1990.

Carlson, L. (2003). Rethinking Normalcy, Normalization, and Cognitive Disability. In R. Figueroa, \& S. Harding (Eds.), Science and Other Cultures: Issues in Philosophies of Science and Technology (pp. 154-171). New York: Routledge (Taylor and Francis).

Finn, R. (1991) "Different Minds”, Discover Magazine, June 1991.

Leibniz, Gottfried Wilhelm Freiherr von, 1714, The Monadology, George Montgomery and Albert R. Chandler, trans. in The Rationalists, Doubleday: New York, 1960, 1990.

Locke, J. (1690). An Essay Concerning Human Understanding, in The Empiricists, Doubleday: New York: 1961, 1990.

MacIntyre, A. (1999). Dependent Rational Animals: Why Human Beings Need the Virtues. Chicago, IL: OpenCourt.

Mitchell, D., \& Snyder, S. (2003). "The Eugenic Atlantic: race, disability, and the making of an international Eugenic Science, 1800-1945” in Disability and Society, vol.18, no. 7, December 2003, pp.843-864.

Silberman, S. (2003). "The Key to Genius.” Wired, issue 11.12-December 2003 http://www.wired.com/ wired/archive/11.12/genius_pr.html The Condé Nast Publications Inc.

Silvers, A., \& Stein, M. A. (2003). Essentially Empirical: The Roles of Biological and Legal Classification in Effectively Prohibiting Genetic Discrimination. In R. Figueroa, \& S. Harding (Eds.), Science and Other Cultures: Issues in Philosophies of Science and Technology (pp. 129-153). New York: Routledge (Taylor and Francis).

Stocking, S. et al. (2003). Summary of Discussion of Williams Syndrome, Autism, and Consciousness" (Summary prepared by Seth Stocking, Kevin Driscoll, Thomas Pellathy, Nicole Kurz, and William Fields, additions and comments by Frawley. http://www.udel.edu/billf/willautconsc.html

Strawson, P. F. (1963), reprint 1993. Freedom and Resentment. Proceedings of the British Academy 48, pp. 1-25; reprinted in perspectives on Moral Responsibility, John Martin Fischer and Mark Ravizza, eds. Ithaca, NY: Cornell U.P., pp 45-66.

Tremain, S. (ed.) (2005). Foucault and the Government of Disability, Ann Arbor: University of Michigan Press.

Wasserman, D. et al (eds), (2005). Quality of Life and Human Difference: Genetic Testing, Health Care, and Disability. Cambridge Studies in Philosophy and Public Policy, New York: Cambridge University Press.

Thompson, P. M., Lee, A. D., Dutton, R. A., Geaga, J. A., Hayashi, K. M., Eckert, M. A., et al. (2005). Abnormal cortical complexity and thickness profiles mapped in Williams Syndrome. Journal of Neuroscience, 25(16), 4146-4158, April 20. 